THE BIRDS OF

Pennsylvania 



\section{THE BIRDS OF}

Pennsyluania

\section{Gerald M. McWilliams}

Naturalist

\section{Daniel W. Brauning}

Ornithologist, Pennsylvania Game Commission

WITH A FOREWORD BY

\section{Kenn Kaufman}

Field Editor, Audubon Magazine

COMSTOCK PUBLISHING ASSOCIATES a division of CORNELL UNIVERSITY PRESS | ITHACA AND LONDON 
Copyright (C) 2000 by Cornell University

All rights reserved. Except for brief quotations in a review, this book, or parts thereof, must not be reproduced in any form without permission in writing from the publisher. For information, address Cornell University Press, Sage House, 512 East State Street, Ithaca, New York 14850.

First published 2000 by Cornell University Press

Printed in the United States of America

Cornell University Press strives to use environmentally responsible suppliers and materials to the fullest extent possible in the publishing of its books. Such materials include vegetablebased, low-VOC inks and acid-free papers that are recycled, totally chlorine-free, or partly composed of nonwood fibers. Books that bear the logo of the FSC (Forest Stewardship Council) use paper taken from forests that have been inspected and certified as meeting the highest standards for environmental and social responsibility. For further information, visit our web site at www.cornellpress.cornell.edu.
Library of Congress Cataloging-in-Publication Data

McWilliams, Gerald M.

The birds of Pennsylvania / Gerald M. McWilliams and Daniel W. Brauning : with a foreword by Kenn Kaufman.

p. $\quad \mathrm{cm}$.

Includes index.

ISBN 0-8014-3643-5 (cloth)

1. Birds-Pennsylvania. 2. Birds-Pennsylvania-

Geographical distribution I. Brauning, Daniel W. II. Title.

QL684.P4M36 1999

598'.09748 - dc21 99-38164

$\begin{array}{lllllllllll}\text { Cloth printing } & 10 & 9 & 8 & 7 & 6 & 5 & 4 & 3 & 2 & 1\end{array}$ 
I am indebted to my wife, Linda, who spent many long hours with me in the preparation of this book, who was patient with my impatience during the long evenings of writing, and who managed to endure nearly a decade with a bird-obsessive writer; and to my sons, Nathan and Aaron, who grew into men during the time it took to write this book. I will always be grateful for their understanding in my absence.

Jerry McWilliams

I would like to express particular appreciation to my wife, Marcia, for her enduring patience during the preparation of this book and for sharing with me a fascination with creation. Also, to my sons, Timothy, Andrew, and David, for their understanding when Dad was glued to his desk. My parents, Marilyn and Wayne Brauning, deserve my gratitude for giving me the freedom to pursue this hobby and unlikely career and for supporting me in my enjoyment of birds.

Soli Deo Gloria

Daniel Brauning 